\title{
Making a Motivated Manager: A Census Data Investigation into Efficiency Differences Between Franchisee and Franchisor-Owned Restaurants
}

\author{
by
}

\author{
Matthew Sveum* \\ University of Missouri Columbia
}

Michael Sykuta

University of Missouri Columbia

CES 16-54 December, 2016

The research program of the Center for Economic Studies (CES) produces a wide range of economic analyses to improve the statistical programs of the U.S. Census Bureau. Many of these analyses take the form of CES research papers. The papers have not undergone the review accorded Census Bureau publications and no endorsement should be inferred. Any opinions and conclusions expressed herein are those of the author(s) and do not necessarily represent the views of the U.S. Census Bureau. All results have been reviewed to ensure that no confidential information is disclosed. Republication in whole or part must be cleared with the authors.

To obtain information about the series, see www.census.gov/ces or contact J. David Brown, Editor, Discussion Papers, U.S. Census Bureau, Center for Economic Studies 5K034A, 4600 Silver Hill Road, Washington, DC 20233, CES.Papers.List@census.gov. To subscribe to the series, please click here. 


\begin{abstract}
While there has been significant research on the reasons for franchising, little work has examined the effects of franchising on establishment performance. This paper attempts to fill that gap. We use restricted-access US Census Bureau microdata from the 2007 Census of Retail Trade to examine establishment-level productivity of franchisee- and franchisor-owned restaurants. We do this by employing a two-stage data envelopment analysis model where the first stage uses DEA to measure each establishment's efficiency. The DEA efficiency score is then used as the second-stage dependent variable. The results show a strong and robust effect attributed to franchisee ownership for full service restaurants, but a smaller and insignificant difference for limited service restaurants. We believe the differences in task programability between limited and full service restaurants results in a very different role for managers/franchisees and is the driving factor behind the different results.
\end{abstract}

Keyword: Franchising, restaurants, data envelopment analysis, efficiency

JEL Classification: D23, D24, L83

\footnotetext{
${ }^{\dagger}$ Any opinions and conclusions expressed herein are those of the authors and do not necessarily represent the views of the U.S. Census Bureau. All results have been reviewed to ensure that no confidential information is disclosed. Support for this research at the Minnesota RDC from NSF (ITR-0427889) and at the University of Missouri Research Data Center is also gratefully acknowledged. We are also grateful for the comments from seminar participants at the Center for Economic Studies at the Census Bureau for their helpful comments. All errors are our own. *Corresponding author: comments are welcome at sveumm@missouri.edu
} 


\section{Introduction}

Franchise organizations have long been a subject of interest in the management and organizational economics literatures. Neither strictly hierarchical nor purely market-based transactions, franchises perhaps represent the quintessential hybrid form of governance (Ménard, 2004). This interest has led to a large literature on the reasons for franchising and the implications for the structure of franchise agreements (Lafontaine and Blair, 2005). While alternate theories have been advanced, the dominant theory and the one with the most consistent empirical support is that franchising reduces the agency costs between the franchise concept owner and the operator of the local establishment (Rubin, 1978 , Lafontaine and Blair, 2005).

Franchising also plays an important role in the economy. According to the US Census, in 2012 franchise-related businesses accounted for 16 percent of retail sales (over $\$ 1.2$ trillion) and 13 percent of employment across a broad array of 18 economic sectors at NAICS 2-digit level (Census, 2012). While the full-service restaurant industry reflects the national average, almost 70 percent of limited-service restaurant sales and 73 percent of employment are occur in franchise establishments.

Despite the economic importance of franchise organizations and the breadth of academic research on the motivations for franchising, there is a paucity of empirical research on the actual economic effect of franchising on the performance of the firm. The principal-agent argument for the use of franchising suggests franchisee-owned establishments should be more efficient than manger-operated locations owned by the franchisor. Previous research has been limited to relatively small case samples that may not be generalizeable to franchises as a whole. In this paper, we use micro-level establishment data from the 2007 US Census of Retail Trade for every franchise-related establishment in the restaurant industry to test whether the franchise ownership structure is associated with differences in performance. Using a two-stage data envelopment analysis method, we find that franchisee-ownership is associated with an increase in establishment-level efficiency for full-service restaurants, but not as clearly for limited-service restaurants.

The rest of the paper is outlined as follows: Section 2 contains a review of the franchising literature and the literature surrounding the tools for measuring productivity in retail, including data envelop- 
ment analysis. Section 3 presents the analytical tools used, while Section 4 outlines the Census data that are used in this paper. Section 5 presents the results from the models and Section 6 summarizes the findings.

\section{Literature Review}

\subsection{The Franchise Relationship}

Reducing the impact of the principal-agent problem is one of the primary reasons for implementing franchising (Lafontaine, 1992). A non-owner manager has a set of incentives that are, at the very least not perfectly aligned with, and at the worst run counter to, his employer's interests. The manager who receives a set salary has little incentive to go above-and-beyond the basic job description if it involves any more than a minimal amount of work. If his extra work increases company profits, but his salary does not change, there is no incentive to work harder. And even if the manager is given financial incentives for performance, any measure of store-level performance is likely to be manipulable by the manager, making the measure itself subject to the manager's shirking behavior. This problem is amplified when monitoring costs are high (Affuso, 2002). If a company has stores spread out across a geographically large region, it may be hard for the headquarters to know what is happening at the local level. Managers who know that they are not closely monitored also know that they can get away with non-profit maximizing activities.

The manager's incentive to shirk can be mitigated by giving the manager a larger share of the profits through franchising (Lafontaine and Blair, 2005). When the manager becomes the establishment's owner, he becomes the residual claimant on the profits from the store he owns, net of the fees due the franchisor. This means that a franchisee's own utility is much more closely related to the company's profits than a manager's. Unlike a manager, the owner receives the benefits, and incurs the consequences, of his efforts.

Although franchise ownership improves incentives for the franchisee vis a vis a manager, the nature of the franchise relationship creates other conflicting incentive structures. Because the franchisee 
incurs all the costs of operations but remits a percentage of the gross sales to the franchisor in royalty fees, the frnanchisee may have incentive to underinvest in certain quality- and revenue-enhancing activities. Moreover, franchisees may free-ride off the investments of other franchisees or the franchisor in developing the brand value of the franchise. Likewise, franchisors may freeride off the investment of franchisees. Franchise contract terms attempt to mitigate these incentive conflicts by granting franchisees territorial monopolies to limit free-riding, requiring advertising expenditures by the franchisee, and requiring advertising and production innovations by the franchisor (Brickley, 1999 , Bhattacharyya and Lafontaine, 1995, Lafontaine and Blair, 2005).

That franchising is a potential solution to the principal-agent problem is well documented in the literature and the assumptions of agency underlie much of the research on franchise contract design. However, there is relatively little work that empirically validates the importance or effectiveness of franchising in mitigating the agency problem and improving establishment level performance. Norton (1989) looked at various problems that franchising is designed to combat, such as monitoring costs due to geographic dispersion and the importance of location-specific knowledge. He examines the impact of franchising by looking at how productivity differs between franchised stores and non-franchised stores. He finds that each of his measures of agency costs have a negative impact on productivity, but that franchising mitigates the impact. In other words, the impact is lower across the board for franchised stores than non-franchised stores. Norton uses labor productivity as his measure of productivity because of data availability. Other papers have also found some support for the idea that franchiseeowned establishments perform better. Shelton (1967) found that franchisee-owned establishments have higher profit. Beheler et al. (2008) used health department scores to measure quality and found that franchisee-owned establishments performed better in health inspections. They conclude that franchisees work harder and achieve better outcomes than franchisor-owned establishments. All three of these papers, though, use relatively small and geographically limited samples, limiting the degree to which their results might be generalized.

Our study is designed to take a broader look at this question. Like Norton, we use productivity as our measure of a restaurant's performance 11 We use productivity rather than profit for a number

\footnotetext{
${ }^{1}$ In this paper, we will use productivity and efficiency interchangeably. This follows the DEA literature.
} 
of reasons. First, profit is rarely used in franchise contracts as a unit of measure. Franchisees almost always pay royalties based on revenues instead of profits (Rubin, 1978). Rubin suggests that this is because revenues are easier to monitor and more difficult for franchisors to manipulate than are profits, which could include expense that effectively represent consumption by the franchisor. This implies that profits are not a good tool for tracking the gains from franchising. Previous research has also suggested revenue may be a flawed measure of performance, since it is greatly impacted by demand and local prices. It may be the logical unit of measurement for a franchisor to monitor franchisees (a franchisor doesn't care if revenues are artificially high because of a force outside of the manager's control), but it would introduce too much information beyond the franchisee's control to make it a good stand-alone measurement here. In other words, a franchisee who has no idea what he is doing may still have high revenues due to being in a good location. Therefore, we follow Norton $(1989)$ and use productivity, which mitigates the effects of consumer demand and focuses on how inputs are used to generate output. In the next subsection, we turn out attention to the best means of measuring restaurant productivity.

\subsection{Measuring Productivity}

To be able to examine if there is a difference between franchisee-owned and franchisor-owned restaurants, it is necessary to accurately measure each restaurant's productivity. Productivity is harder to measure in retail and the restaurant industry than in factory production. While there have been numerous papers written on the topic of measuring productivity in retail, a commonly agreed upon measure has proven to be elusive Achabal, Heineke and McIntyre, 1984, Reynolds and Thompson, 2007).

The most commonly used tool is a partial-factor productive (PFP) measure created by computing the ratio of some measure of output to some measure of input. Typically this takes the the form of sales, revenue, or transactions divided by employees, payroll, or square feet (Reynolds and Thompson, 2007). The PFP approach is popular because it is very easy to compute, and the data are relatively easily available. There is also a certain appeal because of its similarity to marginal productivity. For 
this reason, many companies use this measure to evaluate stores. This approach works well if the research question focuses on a particular input. For example, PFP may work well to determine how a change in technology impacts worker productivity. However, when the question is addressing the entire establishment, using partial factor productivity provides ignores the importance of other inputs to the production process.

An improvement over partial factor productivity is total factor productivity (TFP) (Reynolds, 1998). TFP is widely used with manufacturing data. It is calculated by measuring unexplained variations in output. Generally, TFP regresses output on a series of inputs and then measures the residuals. The most efficient establishments are the ones that have the largest positive residuals because they get the most output relative to their "expected" or predicted output based on their inputs and the estimated parameters of the regression function. Despite its popularity for studies of manufacturing firms, TFP has some downsides that make it impractical for retail sales, and particularly for restaurants. First, TFP is a parametric regression technique that allows for only one output and assumes a unique production function for all firms in the sample. Restaurants of different types use arguably different production functions and have different types of revenue streams. For instance, a restaurant with a drive-thru may have require a different combination of labor and fixed assets such as kitchen and seating than a similar establishment with no drive-thru. The Census data used here allow us to consider multiple outputs that are informative into the operations of the restaurant (see Section 4 for more details). Similarly, the nature of production in a fresh made-to-order sandwich restaurant with no fried foods is arguably different than an establishment with pre-prepared foods. This would suggest a homogeneous parametric production specification would be inappropriate. Finally, Census restaurant data does not provide the extensive input data that Census manufacturing data do. Papers that use TFP on Census manufacturing data are able to access detailed information on the plant's capital and employment. This granular data is not available for the restaurant and retail industries.

Data envelopment analysis (DEA) is a nonparametric approach designed to deal with the problems of TFP. It still creates a ratio of outputs to inputs, but without requiring that prices or input weights be specified. DEA is a linear programming technique that allows for multiple inputs and outputs 
(Donthu and Yoo, 1998; Metters et al., 1999, Ray, 2004). It calculates output to input ratios using shadow prices as the weights. Unlike total factor productivity, DEA allows for each location (or decision-making unit [DMU], in the language of the literature) to have different weights on inputs and outputs. These weights are set so that each individual DMU has the highest possible efficiency score given their inputs and outputs. Another distinguishing characteristic of DEA is that it uses the best performing DMUs as the basis on which all other DMUs are evaluated. These best performing stores earn an efficiency score equal to one. All other, less efficient, DMUs earn an efficiency score less than one. Mathematically, the goal of DEA is to pick weights, the $V_{i}$ 's and $U_{i}$ 's in equation 1 for the inputs and outputs so that the ratio is as high as possible. However, DEA stipulates that unit $i$ 's weights, when applied to unit $j$ 's inputs, won't make unit $j$ 's ratio larger than one. Formally, this take the following form:

$$
\Theta_{i}=\frac{U_{1, i} Y_{1, i}+\ldots+U_{n, i} Y_{n, i}}{V_{1, i} X_{1, i}+\ldots+V_{m, i} X_{m i}}
$$

where $\Theta_{i}$ is the calculated efficiency score for establishment $i$, the $Y$ 's are the outputs, the $X$ 's are inputs, and the $U$ 's and $V$ 's are weights set within the DEA process. The linear programming behind DEA starts with the best performing (or more efficient) stores and then forces all other establishments' efficiency scores to be lower. This means that the DMUs are compared with the best-performing units instead of the average unit.

DEA has been used in many studies examining the relative productivity or efficiency of retail establishments. Joo et al. (2009) use DEA to examine productivity of coffee shops in the Seattle, WA area. They use a few different model specifications in order to pinpoint places of inefficiency within the coffee shops. They use only financial data, which they point out as a weakness of their paper.

Hwang and Chang (2003) used DEA to calculate the efficiency of hotel chains in Taiwan. They use a combination of financial and physical measures for inputs and outputs. Their input measures included the number of rooms, number of employees, and operating expenses. Their output measures are revenue from rooms, food, and other. They also employ a special technique to determine how productivity changes over time. 
Keh and Chu (2003) use DEA to measure performance in the grocery industry. Using data from an undisclosed American grocery chain, the authors measure inputs as capital and labor and outputs as accessibility, assortment, assurance of product deliverability, availability of information, and ambiance. They argue that these outputs capture all of the things that the grocery stores are actually selling.

Reynolds and Thompson (2007) use DEA to compare productivity in restaurants. They argue that only inputs that are beyond the control of the manager in the short run (such as location or the number of parking spaces) should be included in the analysis. They then take the efficiency score generated from the DEA process and use it as a dependent variable in regressions. The independent variables in these regressions are the controllable inputs. This allows the authors to examine how controllable inputs determine a store's efficient use of uncontrollable inputs.

Finally, Botti, Briec and Cliquet (2009) use DEA to examine how franchising impacts chain-level productivity of French hotel chains. They use DEA to determine that French hotel chains that employ a mix of franchisee and franchisor-ownership are more efficient than chains that have a single ownership type. While this is similar to our work here, we depart from Botti et al. in two significant areas. First, they are using chain-level data instead of establishment-level data. Establishment-level data allow for a much more robust analysis because of the larger degree of variation. Second, they do not conduct second-stage regression analysis. They use a Kruskal-Wallis test to determine differences between organizational types, but they do not employ regression analysis. These two factors make this work a significant step beyond where they ended.

\section{Empirical Methods}

This paper makes use of two-stage DEA, in which a DEA efficiency score is computed in stage one, and then is used as the dependent variable in a second-stage regression analysis. That allows for an examination of the determinants of the efficiency score, including franchisee-ownership.

We break the universe of franchise restaurants into two logical subsectors: limited service (fast food) and full service (wait service). We argue that full service restaurants have a meaningfully different production function from limited serve as reflected in the additional customer service and ability to 
up-sell throughout the dining experience. This places a greater managerial emphasis on performance margins that are more difficult to monitor remotely.

We compute two efficiency scores for each sector sample. The first efficiency score comes from a DEA specification with multiple outputs. For limited service, these outputs are sales from the drivethru, sales from counter service (ordering at a counter and taking the food to a table), and sales from takeout. For full service, the outputs are sales from takeout and sales from wait service. All of these are in dollars. The use of multiple outputs is a key distinctive feature of DEA that can not be done with more traditional measures of productivity. The advantage here is that it controls for different types of establishments. Establishments that have very few seats may look very efficient, but that is corrected when sales are split between takeout, counter, and drive-thru sales. Now a restaurant that has few seats and no counter sales but good takeout sales doesn't look more efficient compared with a restaurant with the same dollar amount of sales, all of which come from counter service, and has a large number of seats. The second DEA specification uses total sales as the output, in dollars. Total sales includes all of the areas outlined above, but also includes some smaller aspects of a restaurant's business, such as catering $2^{2}$

In all DEA specifications the inputs are payroll, age of the establishment, and the number of seats. Payroll represents the level of employment at the establishment. Age represents the institutional knowledge that the establishment has built up over time. Seats represents the amount of capital that the establishment has. Together, these three inputs cover a wide range of the resources that the establishment has at its disposal to generate output. A more detailed explanation of the variables is saved for Section 4

The output from the DEA becomes the dependent variable in the second stage. In this stage, we run the following regression:

$$
\Theta_{i, j}=\beta_{0}+\beta_{1} \text { franchisee }_{i}+\mathbf{X}_{i} \delta+\gamma
$$

\footnotetext{
${ }^{2}$ Some establishments report atypical categories of revenue. For example, a full service restaurant with drive-thru sales. These establishments are not excluded because of the wide variety of establishment types. However, atypical sources of revenue make up a small percentage of revenue in both sectors.
} 
where $\Theta_{i}$ is the calculated efficiency score from DEA specification $j$ for establishment $i,(\text { franchisee })_{i}$ equals one if establishment $i$ is owned by a franchisee, $\mathbf{X}_{i}$ is a vector of establishment characteristics that can take various forms (e.g., whether it has a drive-thru or how many establishments its owner owns), and $\gamma$ is a vector of chain fixed effects to control for differences across chains.

There is some debate in the DEA literature surrounding the correct technique in two-stage DEA. Simar and Wilson (2007) argue that conventional OLS and Tobit are not appropriate because DEA efficiency scores are generated in a specific way, and are bounded by definition instead of by censoring. They present evidence that using OLS or Tobit will lead to biased results in the second stage under certain conditions. On the other hand, McDonald (2009) argues that OLS is acceptable when the inputs in the first stage are independent of the second-stage variables. This is the case with franchiseeownership, which is the key second-stage variable of interest. As Emerson (1993) describes in his legal analysis of franchise contracts, standards about the operation of the establishment, including its size, location, and employment levels, are specified by the franchisor. This suggests the essential input requirements are independent of the establishment ownership (by franchisor or franchisee). Sveum (2016) conducts a Monte Carlo simulation of the two-state DEA process using data generated to mimic restaurant establishment production and applies an independent "franchising effect" to a random subsample of observations. He finds that a two-stage estimation process using OLS regression provides a more consistent and more accurate estimate of the known effect than the bootstrapping process recommended by Simar and Wilson (2007). Consequently, we use a second stage OLS model for the results reported below. 3

If the agency theory of franchising is correct, then we would expect $\beta_{1}$ to be positive. This would signal that establishments that are franchisee-owned have higher efficiency scores than franchisorowned establishments. Additionally, the magnitude of $\beta_{1}$ shows how much more efficient the average franchisee-owned establishment is over the average franchisor-owned establishment. If the estimate for $\beta_{1}$ is negative, that would signify that franchisee-owned establishments are less efficient than their franchisor-owned counterparts.

\footnotetext{
${ }^{3}$ We did also run the model using a bootstrap method for robustness sake. The results are not substantively different than those presented here.
} 


\section{Data}

Our data come from the United States Census Bureau's 2007 Census of Retail Trade (CRT). The CRT is conducted every five years, in years ending in 2 and 7,4 As part of the larger economic census, the CRT covers all retail and restaurant establishments. Responses to the CRT are required by law, and the Census Bureau takes great strides to assure compliance. In exchange for mandatory responses, Census guarantees the confidentiality of individual responses. While establishment-level data are available to researchers in a controlled environment, only aggregated summary statistics and regression coefficients can be reported.

In order to narrow the scope of the data, we limit the sample to establishments in the full service (NAICS code 72211) and limited service (NAICS code 722211) restaurant subsectors. There are two reasons for this: first, franchising is very common within the food services industry, and second, more input data is available for restaurants than for other industries. In 2007, 14 percent of full service restaurants and 59 percent of limited service restaurants were affiliated with a franchise, making it a good sector for analysis:5 The second reason is one of data convenience. Different types of establishments receive different questions on their survey forms. Restaurants are asked about the number of seats, which provides for an input into production other than the number of employees or dollars spent on payroll.

After being restricted to establishments in full and limited service restaurants, the sample was further restricted to establishments that have a franchise affiliation. On the Census form, establishments are asked "was this establishment operating under a trademark authorized by a franchisor in 2007?" Establishments are given three response options:

1. "yes - franchisee owned establishment,"

2. "yes - franchisor owned establishment," or

3. "no."

\footnotetext{
${ }^{4}$ Data for the 2012 CRT were not released until after this analysis had been completed.

${ }^{5} \mathrm{~A}$ summary of franchising from the 2007 Economic Census can be found at https://www.census.gov/newsroom/ releases/archives/economic_census/cb10-141.html
} 
Table 1: Summary of the definitions for each input and output variable.

\begin{tabular}{ccccl} 
Variable & Type & $\begin{array}{c}\text { Limited } \\
\text { Service }\end{array}$ & $\begin{array}{c}\text { Full Service } \\
\text { Service }\end{array}$ & Meaning \\
\hline Total Sales & Output & $\checkmark$ & $\checkmark$ & Total revenue; $\$ 1000$ 's \\
drive-thru Sales & Output & $\checkmark$ & & Revenue from drive-thru; $\$ 1000$ 's \\
Counter Sales & Output & $\checkmark$ & & Revenue from counter service; $\$ 1000$ 's \\
Takeout Sales & Output & $\checkmark$ & $\checkmark$ & Revenue from takeout; $\$ 1000$ 's \\
Server Sales & Output & & $\checkmark$ & Revenue from a waiter; $\$ 1000$ 's \\
Payroll & Input & $\checkmark$ & $\checkmark$ & Dollars spent on employees \\
Age & Input & $\checkmark$ & $\checkmark$ & Years since the establishment was founded \\
Seats & Input & $\checkmark$ & $\checkmark$ & Number of seats in the establishment \\
Competitors & Control & $\checkmark$ & $\checkmark$ & Number of competitors in the same zip code \\
Units & Control & $\checkmark$ & $\checkmark$ & Number of estabs. under the same ownership \\
\hline \hline
\end{tabular}

All establishments that responded with the third option are dropped. Additionally, some establishments were reported as giving other responses, which are also dropped. This leaves in the sample only establishments that are owned by either a franchisee or a franchisor.

The inputs and outputs used are listed in Table 1. The selection of inputs and outputs is somewhat limited within the CRT. The best measure of output is sales. While sales is not ideal, because of its inclusion of price, it still provides a measure of the amount of output generated by the establishment. Sales here are measured in thousands of dollars, and cover all sales from 2007. The CRT also provides data on how sales are generated. Establishments are asked for either their dollar sales or the percentage of sales coming from a variety of different areas. Of interest to the analysis here (mostly because they account for a large percentage of sales across all establishments) are sales from drive-thrus, counter service, takeout, and servers. For limited service restaurants we use drive-thru, takeout, and counter sales. For full service restaurants we use takeout sales and server sales. By using a full picture of sales and a categorical view of sales we are able to better understand how establishments operate, and better account for differences in establishment type. For example, a fast food establishment that only has takeout and a drive-thru may use employees differently than an establishment that has a large dining room. By using a version of DEA with multiple outputs we can better disentangle these differences.

The primary choices for input measures from the available CRT data are payroll, employees, and seats. Seats is defined as the number of seats, including patio and bar seats, within the establishment. Seats acts as a measure of the physical capital available to the establishment. Presuming that most 
establishments do not want to have large sections of their dining room open without seats, the number of seats is not easily changed by the manager. In other words, the number of seats can serve as a measurement of serving capacity. This is especially true in full service restaurants. With limited service restaurants, it is likely that a significant percentage of business is coming from take-out, delivery, or the drive-thru. However, even with that being true, the number of seats serves as a measure of expected customer volume.

Payroll is measured as thousands of dollars spent on employees during the entire year of 2007 . Employment is also a measure of workforce size, but is measured as the number of employees during the week containing March 12. This means that employment is a weaker measure of the workforce than payroll because it can be influenced by unique events on March 12. For example, an establishment that opened on April 1 would have positive payroll for 2007, but no employees. We use only payroll in our analysis because of the oddities in the construction of employment. Another reason for using payroll is the high use of part-time employment in restaurants. By using payroll, we do not need to worry whether a particular restaurant has fewer employees working more hours or more employers working fewer hours. Finally, because we are using dollar sales as the output measure, using a dollardenominated input helps control for regional differences in general price levels or costs of living.

We create a few additional control variables from Census responses. The first is the number of other establishments competing within the same area, defined as the number of establishments within the same zip code that share the same line of business ${ }^{6}$ Establishments are asked by Census what type of product they sell most. It makes more sense to limit competitors to establishments in the same line of business than it does to include all food establishments. While a sit down fine dining restaurant and a fast food restaurant are both food establishments, they are not likely competing as directly for customers on a given day. The same people might patronize both establishments, but potential customers are likely not deciding between the two for that night's dinner. The number of competitors is used as a measure of competition, which indicates how much effort is needed to win customers. Much less effort is needed to woo customers when there are no competing firms than if the establishment is on a crowded main street. However, there might also be network effects going on; a

\footnotetext{
${ }^{6}$ Establishments are asked to pick a "principle menu type", such as Italian, Mexican, seafood, steak, pizza, etc.
} 
large number of establishments might indicate high consumer demand, which could cause higher sales.

We control for the age of the establishment, which is defined as 2008 minus the year that the establishment was founded. The data are left-censored in 1976, so the oldest establishments in the data are listed as 32 years old. The age of the the establishment serves as a measure of reputation and learning-by-doing. One of the reasons why companies franchise is to gain access to local information held by the franchisee. The longer the establishment is open, the more local information is gathered. It also serves as a measure of how well-known the establishment is in the community. A longer existing establishment has had more time to build name recognition among potential customers.

State fixed effects are computed by using the state that appears for the establishment in the Business Register. This is intended, in part, to control for state-level regulations on franchising that may affect the relationships between franchisees and franchisors. Establishments are not evenly spread across the country. The state with the smallest representation in the sample is Alaska in the full service subsector, with only 15 establishments. A visual representation of where establishments are located is found in Figure 1 .

Figure 1: Maps showing where establishments in the two samples are located.

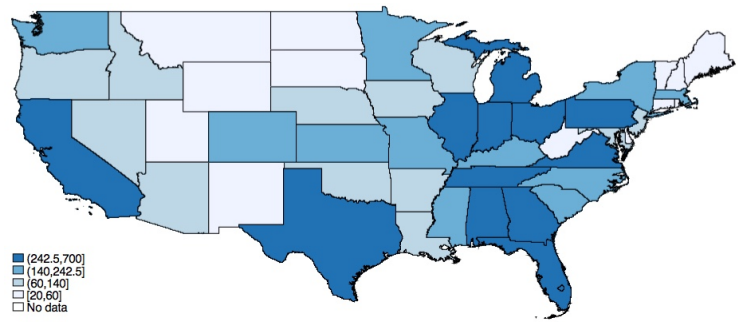

(a) Full Service

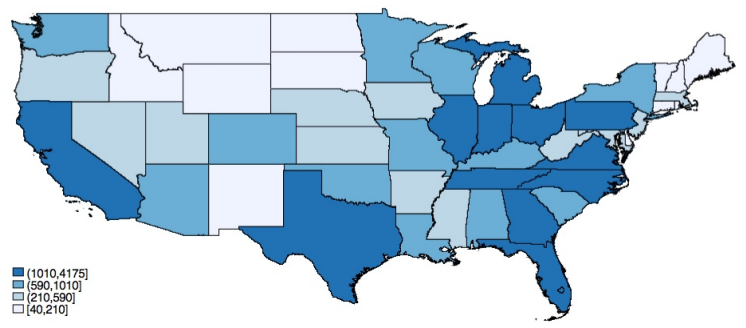

(b) Limited Service

We also include Census tract demographic information from the American Community Survey. This data includes the population of the Census tract and the median income. While Census tracts are small, this gives an indication of where the restaurant is located. Higher population and/or higher income shows that the restaurant is in a busy areas instead of along a deserted highway.

Finally, we create a variable containing the number of establishments owned by the same owner. This could be the franchisor, a single franchisee, or a corporate franchisee. While our analysis here treats franchisees as a single owner-operators, that is not always the case. However, the analysis shows 
that this distinction is not a major concern.

Establishment names are important to be able to control for differences between chains. Because each establishment - both franchisee-owned and franchisor-owned - operates within the prescribed rules set forth by the franchisor, the effect of franchisee ownership is likely different between chains. To determine the chain to which an establishment belongs, we use administrative data linked to the CRT. Establishments are asked to provide a name for their establishment, and are given two blanks. One is intended to be a legal name, and the other a "doing business as." However, there is a fair amount of variation in the way responses were given. To get around this, we started with a list of all chains that have appeared in the Franchise 500 at any point between 2004 and 2014. If either name field contains the name of a known franchise chain, the establishment takes that name. We also added names to the list generated from the Franchise 500 based on observations of trends in the non-matched data. After searching, and then standardizing, names, about eighty percent of establishments in both subsectors were able to be named 7

Summary statistics for the inputs and outputs for both full and limited service restaurants are in Table 2. Not surprisingly, full service restaurants have higher sales, higher payroll, and more seats than limited service restaurants. On average, both types of restaurants have a similar number of competitors and are the same age. Table 3 breaks down the two sectors into the number and percentage of franchisee-owned and franchisor-owned stores. Both sectors are roughly 70 percent franchisee-owned and 30 percent franchisor-owned. This compares well with other documented percentages. Lafontaine and Shaw (2005) report that 78 percent of establishments in their Franchise 500 data, which is from the 1980's, are owned by franchisors. Additionally, Nation's Restaurant News reports that 73 percent of franchise-affiliated establishments in their Top 200 are owned by franchisees in 2014.

\section{Results \& Discussion}

Summary statistics for the DEA step are found in Table 4 . These efficiency scores have been scaled up, so the range is between 0 and 100. Recall, for each subsector there are two efficiency scores, one for

\footnotetext{
${ }^{7}$ Because of Census policies on disclosure, the matched chains can not be listed.
} 
Table 2: Summary statistics for the input and output variables.

\begin{tabular}{cccc|ccc} 
& \multicolumn{3}{c}{ Full Service } & \multicolumn{3}{c}{ Limited Service } \\
\cline { 2 - 7 } Variable & $\mathrm{N}$ & Mean & St. Dev. & $\mathrm{N}$ & Mean & St. Dev. \\
\hline Total Sales & 8900 & 1583.21 & 1023.4 & 40000 & 1231.36 & 708.44 \\
Counter Service Sales & 8900 & 15.26 & 125.47 & 40000 & 502.05 & 445.59 \\
drive-thru Sales & 8900 & 41.04 & 147.94 & 40000 & 592.77 & 216.62 \\
Takeout Sales & 8900 & 180.63 & 253.84 & 40000 & 122.11 & 231.49 \\
Server Sales & 8900 & 1254.07 & 982.64 & 40000 & 14.28 & 113.78 \\
Seats & 8900 & 131.01 & 72.13 & 40000 & 69.48 & 41.01 \\
Years of Existence & 8900 & 14.62 & 9.96 & 40000 & 14.21 & 9.42 \\
Number of Competitors & 8900 & 28.88 & 19.42 & 40000 & 25.8 & 18.61 \\
Employment & 8900 & 43.28 & 24.97 & 40000 & 27.75 & 16.58 \\
Payroll & 8900 & 534.6 & 374.07 & 40000 & 314.02 & 178.49 \\
\hline \hline
\end{tabular}

Table 3: Percentage of establishments in the sample that are franchisee-owned and franchisor-owned.

\begin{tabular}{ccc} 
& Full service & Limited service \\
\hline Franchisee-owned & $65 \%$ & $78 \%$ \\
Franchisor-owned & $35 \%$ & $22 \%$ \\
\hline \hline
\end{tabular}

the DEA specification with one output, and one for the DEA specification with multiple outputs. The mean efficiency score of 30.88 for the multiple output full service specification suggests that the average full service establishment is $30.88 \%$ efficient compared with the most efficient full service restaurants in the sample. Because the mean efficiency score decreases as the sample size increases (Zhang and Bartles, 1998), it makes sense that the mean efficiency scores are lower than studies that use very small sample sizes ${ }^{8}$ For both subsectors the mean efficiency score is higher for the multiple output specification. This is because a new output will always increase the efficiency score, on average (just like a new input will always lower efficiency scores, on average).

Table 4: Summary statistics on the DEA efficiency scores, which have been multiplied by 100.

\begin{tabular}{cccc} 
& $\mathrm{N}$ & Mean & St. Dev. \\
\hline Full Service, Multiple Outputs & 8900 & 30.88 & 14.31 \\
Full Service, One Output & 8900 & 27.39 & 11.76 \\
Limited Service, Multiple Outputs & 40000 & 13.42 & 8.31 \\
Limited Service, One Output & 40000 & 8.26 & 3.33 \\
\hline \hline
\end{tabular}

Results for the second stage are found across Tables 5 to 8 Table 5 contains the results from the limited service subsector and the multiple-output DEA specification. Column (1) shows a positive and significant franchisee ownership effect. However, once chain fixed effects are added in column (2), that

\footnotetext{
${ }^{8}$ The mean efficiency score decreases as the sample size grows because the probability of finding a more efficient firm increases as the sample grows. It is not because of anything in the calculation. Establishments are still only compared with the frontier.
} 
Table 5: Regression results for limited service restaurants. The dependent variable is the DEA efficiency score computed with multiple outputs (drive-thru, counter, and takeout sales). T-statistics are in parentheses. Chain clustering clusters the standard error at the chain level. ${ }^{* * *}=$ significant at the $1 \%$ level, ${ }^{* *}=$ significant at the $5 \%$ level, ${ }^{*}=$ significant at the $10 \%$ level.

\begin{tabular}{|c|c|c|c|c|c|c|c|c|}
\hline & (1) & (2) & $(3)$ & (4) & (5) & (6) & (7) & $(8)$ \\
\hline Franchisee & $\begin{array}{c}0.95^{* * *} \\
(9.5)\end{array}$ & $\begin{array}{c}-0.91^{* * *} \\
(-7.92)\end{array}$ & $\begin{array}{l}-0.91 \\
(-0.72)\end{array}$ & $\begin{array}{l}-0.92 \\
(-0.72)\end{array}$ & $\begin{array}{l}-0.79 \\
(-0.67)\end{array}$ & $\begin{array}{l}-0.78 \\
(-0.66)\end{array}$ & $\begin{array}{c}1.5 \\
(1.08)\end{array}$ & $\begin{array}{l}-0.98 \\
(-0.8)\end{array}$ \\
\hline $\begin{array}{c}\text { Number of } \\
\text { Competitors }\end{array}$ & & & & $\begin{array}{c}0 \\
(-0.09)\end{array}$ & $\begin{array}{c}0 \\
(-0.4)\end{array}$ & $\begin{array}{c}0 \\
(-0.38)\end{array}$ & & $\begin{array}{c}0 \\
(-0.4)\end{array}$ \\
\hline $\begin{array}{l}\text { drive-thru } \\
\text { Dummy }\end{array}$ & & & & & & $\begin{array}{c}0.24 \\
(0.24)\end{array}$ & & \\
\hline Units & & & & & & & $\begin{array}{c}0^{* *} \\
(1.94)\end{array}$ & \\
\hline $\begin{array}{c}\text { Units } \times \\
\text { Franchisee }\end{array}$ & & & & & & & $\begin{array}{c}0^{* * *} \\
(-2.68)\end{array}$ & \\
\hline Income & & & & & & & & $\begin{array}{l}0^{* * *} \\
(2.91)\end{array}$ \\
\hline Population & & & & & & & & $\begin{array}{l}0^{* * *} \\
(2.22)\end{array}$ \\
\hline Constant & $\begin{array}{l}12.69^{* * *} \\
(143.84) \\
\end{array}$ & $\begin{array}{l}10.32 \\
(0.3) \\
\end{array}$ & $\begin{array}{c}10.32 \\
(0.3) \\
\end{array}$ & $\begin{array}{c}10.32 \\
(0.3) \\
\end{array}$ & $\begin{array}{l}11.59 \\
(0.31) \\
\end{array}$ & $\begin{array}{c}11.4 \\
(0.31) \\
\end{array}$ & $\begin{array}{c}7.92 \\
(0.31)\end{array}$ & $\begin{array}{c}9.51 \\
(0.32)\end{array}$ \\
\hline Chain FE & $\mathrm{N}$ & $\mathrm{Y}$ & $\mathrm{Y}$ & $\mathrm{Y}$ & $\mathrm{Y}$ & $\mathrm{Y}$ & $\mathrm{Y}$ & $\mathrm{Y}$ \\
\hline Chain Clustering & $\mathrm{N}$ & $\mathrm{N}$ & $\mathrm{Y}$ & $\mathrm{Y}$ & $\mathrm{Y}$ & $\mathrm{Y}$ & $\mathrm{Y}$ & $\mathrm{Y}$ \\
\hline State FE & $\mathrm{N}$ & $\mathrm{N}$ & $\mathrm{N}$ & $\mathrm{N}$ & $\bar{Y}$ & $\mathrm{Y}$ & $\mathrm{N}$ & $\mathrm{N}$ \\
\hline $\mathrm{N}$ & 40000 & 32000 & 32000 & 32000 & 32000 & 32000 & 32000 & 26000 \\
\hline
\end{tabular}

effect goes negative. There is reason to believe that the error structure is different across chains, and once we cluster standard errors at the chain level, the significance goes away in column (3). Regardless of what other controls are added, the estimated coefficients stay very small and insignificant. Other control variables are significant, such as the number of units, but are too small to have a meaningful economic interpretation.

Table 6 presents the same regressions as the previous table, but uses the DEA score from the single-output specification. Again, little significance is found. Once standard errors are clustered at the chain level, none of the franchisee coefficients are significant. Taken with the results in the previous table, there is little evidence of a franchisee-ownership effect within the limited service subsector.

In Table 7 we present results from the DEA specification with multiple outputs for full service restaurants. For all second-stage specifications, columns (1) to (7), the franchisee effect is positive and significant. This indicates that franchisees make their establishments more efficient than franchisoremployed managers are able to make their establishments. Since the efficiency score is between 0 and 
Table 6: Regression results for limited service restaurants. The dependent variable is the DEA efficiency score computed with total sales as the output. T-statistics are in parentheses. Chain clustering clusters the standard error at the chain level. ${ }^{* * *}=$ significant at the $1 \%$ level, ${ }^{* *}=$ significant at the $5 \%$ level, $*=$ significant at the $10 \%$ level.

\begin{tabular}{|c|c|c|c|c|c|c|c|c|}
\hline & (1) & (2) & (3) & (4) & $(5)$ & (6) & (7) & (8) \\
\hline Franchisee & $\begin{array}{c}0.32^{* * *} \\
(7.92)\end{array}$ & $\begin{array}{l}-0.01 \\
(-0.25)\end{array}$ & $\begin{array}{c}-0.01 \\
(-0.05)\end{array}$ & $\begin{array}{c}-0.01 \\
(-0.05)\end{array}$ & $\begin{array}{c}0 \\
(0.02)\end{array}$ & $\begin{array}{c}0.01 \\
(0.03)\end{array}$ & $\begin{array}{c}0.2 \\
(0.5)\end{array}$ & $\begin{array}{c}-0.03 \\
(-0.14)\end{array}$ \\
\hline $\begin{array}{l}\text { Number of } \\
\text { Competitors }\end{array}$ & & & & $\begin{array}{c}0 \\
(-0.11)\end{array}$ & $\begin{array}{c}-15 \\
(-0.82)\end{array}$ & $\begin{array}{c}0 \\
(-0.81)\end{array}$ & & $\begin{array}{c}0 \\
(0.04)\end{array}$ \\
\hline $\begin{array}{l}\text { drive-thru } \\
\text { Dummy }\end{array}$ & & & & & & $\begin{array}{c}0.11 \\
(0.43)\end{array}$ & & \\
\hline Units & & & & & & & $\begin{array}{c}0 \\
(0.43)\end{array}$ & \\
\hline $\begin{array}{c}\text { Units } \times \\
\text { Franchisee }\end{array}$ & & & & & & & $\begin{array}{c}0 * * * \\
(-5.67)\end{array}$ & \\
\hline Income & & & & & & & & $\begin{array}{c}0 \\
(1.61)\end{array}$ \\
\hline Population & & & & & & & & $\begin{array}{l}0 \\
0\end{array}$ \\
\hline Constant & $\begin{array}{l}8.01^{* * *} \\
(226.44)\end{array}$ & $\begin{array}{c}6.94^{* * *} \\
(9.29)\end{array}$ & $\begin{array}{c}6.94^{* * *} \\
(26.35)\end{array}$ & $\begin{array}{c}6.95^{* * * *} \\
(26.32)\end{array}$ & $\begin{array}{l}8.95^{* * *} \\
(10.57)\end{array}$ & $\begin{array}{c}8.87^{* * *} \\
(9.92)\end{array}$ & $\begin{array}{c}6.75^{* * *} \\
(17.15)\end{array}$ & $\begin{array}{c}6.49^{* * *} \\
(26.73)\end{array}$ \\
\hline Chain FE & $\mathrm{N}$ & $\overline{\mathrm{Y}}$ & $\bar{Y}$ & $\bar{Y}$ & $\bar{Y}$ & $\bar{Y}$ & $\bar{Y}$ & $\bar{Y}$ \\
\hline Chain Clustering & $\mathrm{N}$ & $\mathrm{N}$ & $\bar{Y}$ & $\mathrm{Y}$ & $\mathrm{Y}$ & $\mathrm{Y}$ & $\mathrm{Y}$ & $\mathrm{Y}$ \\
\hline State FE & $\mathrm{N}$ & $\mathrm{N}$ & $\mathrm{N}$ & $\mathrm{N}$ & $\mathrm{Y}$ & $\mathrm{Y}$ & $\mathrm{N}$ & $\mathrm{N}$ \\
\hline $\mathrm{N}$ & 40000 & 32000 & 32000 & 32000 & 32000 & 32000 & 32000 & 26000 \\
\hline
\end{tabular}

100, a coefficient of 3.0 means that the average franchisee-owned restaurant is three percentage points more efficient than a similar franchisor-owned restaurant. At the mean efficiency score, that is about a $10 \%$ increase in efficiency.

These results are robust to various specifications. In column (1) we do not use any controls. As we add in fixed effects - column (2) - and then cluster standard errors at the chain level - column (3) - the results stay consistent. In column (4) we add in a control for the number of competitors in the area. While that coefficient is insignificant, the franchisee ownership coefficient remains positive and significant. In column (6) we control for the size of the ownership group the establishment is in, whether that is the franchisor, or a multiunit franchisee. This controls for large franchisees, and the effect is very small. And in column (7) we control for demographics of the Census tract. In all of these the effect stays between 1.83 and 4.55 , and is significant in all of them.

A very similar pattern emerges for the single output DEA specification. Those results are in Table 8 . The franchisee coefficient is negative and significant in column (1), but that column does not include 
Table 7: Regression results for full service restaurants. The dependent variable is the DEA efficiency score computed with multiple outputs (server and takeout sales). T-statistics are in parentheses. Chain clustering clusters the standard error at the chain level. ${ }^{* * *}=$ significant at the $1 \%$ level, ${ }^{* *}=$ significant at the $5 \%$ level, ${ }^{*}=$ significant at the $10 \%$ level.

\begin{tabular}{|c|c|c|c|c|c|c|c|}
\hline & (1) & $(2)$ & (3) & (4) & (5) & (6) & (7) \\
\hline Franchisee & $\begin{array}{c}1.83^{* * *} \\
(5.86)\end{array}$ & $\begin{array}{c}3.28^{* * *} \\
(6.39)\end{array}$ & $\begin{array}{c}3.28^{* * *} \\
(3.07)\end{array}$ & $\begin{array}{c}3.28^{* * *} \\
(3.09)\end{array}$ & $\begin{array}{c}3.07^{* * *} \\
(2.69)\end{array}$ & $\begin{array}{c}4.55^{* * *} \\
(3.37)\end{array}$ & $\begin{array}{c}3.65^{* * *} \\
(3.56)\end{array}$ \\
\hline $\begin{array}{l}\text { Number of } \\
\text { Competitors }\end{array}$ & & & & $\begin{array}{c}0.01 \\
(0.69)\end{array}$ & $\begin{array}{c}0 \\
(0.24)\end{array}$ & & $\begin{array}{c}0.02 \\
(0.98)\end{array}$ \\
\hline Units & & & & & & $\begin{array}{c}0^{*} \\
(1.67)\end{array}$ & \\
\hline $\begin{array}{c}\text { Units } \times \\
\text { Franchisee }\end{array}$ & & & & & & $\begin{array}{c}0 \\
(-0.81)\end{array}$ & \\
\hline Income & & & & & & & $\begin{array}{c}0 \\
(0.68)\end{array}$ \\
\hline Population & & & & & & & $\begin{array}{c}0 \\
(4.05)\end{array}$ \\
\hline Constant & $\begin{array}{l}2.69^{* * *} \\
(115.64)\end{array}$ & $\begin{array}{c}44.62^{* * *} \\
(17.05)\end{array}$ & $\begin{array}{c}44.62^{* * *} \\
(41.76)\end{array}$ & $\begin{array}{c}44.34^{* * *} \\
(42.23)\end{array}$ & $\begin{array}{c}39.22^{* * *} \\
(12.56)\end{array}$ & $\begin{array}{c}43.3^{* * *} \\
(32)\end{array}$ & $\begin{array}{c}42.37^{* * *} \\
(32.42)\end{array}$ \\
\hline Chain FE & $\mathrm{N}$ & $\mathrm{Y}$ & $\mathrm{Y}$ & $\mathrm{Y}$ & $\mathrm{Y}$ & $\mathrm{Y}$ & $\mathrm{Y}$ \\
\hline Chain Clustering & $\mathrm{N}$ & $\mathrm{N}$ & $\mathrm{Y}$ & $\mathrm{Y}$ & $\mathrm{Y}$ & $\mathrm{Y}$ & $\mathrm{Y}$ \\
\hline State FE & $\mathrm{N}$ & $\mathrm{N}$ & $\mathrm{N}$ & $\mathrm{N}$ & $\mathrm{Y}$ & $\mathrm{N}$ & $\mathrm{N}$ \\
\hline $\mathrm{N}$ & 8900 & 7100 & 7100 & 7100 & 7100 & 7100 & 5500 \\
\hline
\end{tabular}

any controls or fixed effects, or chain standard error clustering. That means that we discount the validity of that coefficient. For all other columns, the franchisee coefficient is positive and significant. Just like in Table 7, the estimated franchisee effect is economically meaningful, although smaller than in the multiple output specification. Here, the franchisee effect ranges from 2.26 to 3.02 , meaning that franchisee-owned full service restaurants are 2.26 to 3.02 percentage point more efficient than their franchisor-owned counterparts. Again, this is about $10 \%$ of the mean efficiency score.

The results presented in Tables 5 to 8 suggest that franchisees have a stronger impact on restaurant productivity in the full service subsector than they do in the limited service sector. Both results are highly robust to different second-stage specifications. Regardless of what control variables are used, the effect in limited service is essentially nonexistent. For full service, the effect ranges from about two percentage points to about four and a half percentage points.

There might be concern that the two different DEA specifications are modeling essentially the same thing, and therefore they are not really a robustness check of one another. However, we do not believe that to be true. The correlation between the two DEA efficiency scores for full service is 0.75 and for 
Table 8: Regression results for full service restaurants. The dependent variable is the DEA efficiency score computed with total sales as the output. T-statistics are in parentheses. Chain clustering clusters the standard error at the chain level. ${ }^{* * *}=$ significant at the $1 \%$ level, ${ }^{* *}=$ significant at the $5 \%$ level, $*=$ significant at the $10 \%$ level.

\begin{tabular}{|c|c|c|c|c|c|c|c|}
\hline & (1) & (2) & (3) & (4) & $(5)$ & (6) & (7) \\
\hline Franchisee & $\begin{array}{c}-0.86^{* * *} \\
(-3.26)\end{array}$ & $\begin{array}{c}2.66^{* * * *} \\
(6.22)\end{array}$ & $\begin{array}{c}2.26^{* * *} \\
(2.68)\end{array}$ & $\begin{array}{c}2.66^{* * * *} \\
(2.69)\end{array}$ & $\begin{array}{c}2.63^{* * *} \\
(2.81)\end{array}$ & $\begin{array}{l}2.29^{*} \\
(1.67)\end{array}$ & $\begin{array}{c}3.02^{* * *} \\
(3.11)\end{array}$ \\
\hline $\begin{array}{l}\text { Number of } \\
\text { Competitors }\end{array}$ & & & & $\begin{array}{c}0 \\
(0.25)\end{array}$ & $\begin{array}{c}0 \\
(-0.13)\end{array}$ & & $\begin{array}{l}0.01 \\
(0.7)\end{array}$ \\
\hline Units & & & & & & $\begin{array}{c}0 \\
(-0.3)\end{array}$ & \\
\hline $\begin{array}{c}\text { Units } \times \\
\text { Franchisee }\end{array}$ & & & & & & $\begin{array}{c}0 \\
(1.34)\end{array}$ & \\
\hline Income & & & & & & & $\begin{array}{c}0 \\
(1.18)\end{array}$ \\
\hline Population & & & & & & & $\begin{array}{c}0^{* * *} \\
(4.12)\end{array}$ \\
\hline Constant & $\begin{array}{c}27.95^{* * *} \\
(132.35)\end{array}$ & $\begin{array}{c}24.99^{* * *} \\
(11.46)\end{array}$ & $\begin{array}{c}24.99^{* * *} \\
(25.21)\end{array}$ & $\begin{array}{c}24.91^{* * *} \\
(25.96)\end{array}$ & $\begin{array}{c}18.47^{* * *} \\
(5.67)\end{array}$ & $\begin{array}{c}25.3^{* * *} \\
(18.43)\end{array}$ & $\begin{array}{c}22.91^{* * *} \\
(20.86)\end{array}$ \\
\hline Chain FE & $\mathrm{N}$ & $\mathrm{Y}$ & $\mathrm{Y}$ & $\mathrm{Y}$ & $\mathrm{Y}$ & $\mathrm{Y}$ & $\mathrm{Y}$ \\
\hline Chain Clustering & $\mathrm{N}$ & $\mathrm{N}$ & $\mathrm{Y}$ & $\mathrm{Y}$ & $\mathrm{Y}$ & $\mathrm{Y}$ & $\mathrm{Y}$ \\
\hline State FE & $\mathrm{N}$ & $\mathrm{N}$ & $\mathrm{N}$ & $\mathrm{N}$ & $\mathrm{Y}$ & $\mathrm{N}$ & $\mathrm{N}$ \\
\hline $\mathrm{N}$ & 8900 & 7100 & 7100 & 7100 & 7100 & 7100 & 5500 \\
\hline
\end{tabular}

limited service is 0.66 . These are fairly high correlations, but is not high enough to cause concern that they are essentially the same. These two DEA efficiency scores are getting at the same thing, but are both useful in examining the franchisee-ownership effect. One is narrowing in on sales type, the other is picking up on other types of sales outside of the main categories (e.g., catering).

So if these results are robust, what conclusions can be drawn? And of specific interest: why does full service see a strong franchisee-ownership effect, whereas limited service does not? On the surface, full and limited service restaurants may not seem that different. Both are places where people go to eat meals away from home. However, the operation is very different. In a limited service restaurant, the manager (or franchisee) is supervising employees who are doing very task-programmable jobs. The manager can train an employee to ask about add-on side items or on how to smile and greet a customer, but there is little customer interaction. The same is not true in full service. In a full service restaurant, employees, especially servers, are spending significant amounts of time with the customers. And as a result, their job is much less task-programmable. A good manager has a lot of opportunity to train servers on how to interact with customers. 
This is why franchisee-ownership matters. If the manager does not have an incentive to aggressively increase the establishment's revenues (or profits) they may not take the time to train servers on how to build a rapport with customers that may lead to more drink, appetizer, or dessert sales. The chain is able to give directions to their employee-managers on how to train servers, but a motivated franchisee can make a big difference.

The fact that the estimated effects on the franchisee coefficients are not very large, especially in limited service, means that franchisors are good at determining whether a new establishment should be franchisee-owned or franchisor-owned. Lafontaine and Shaw (2005) find that franchisors keep a steady ownership mix after about seven years. As the chain expands, the franchisor needs to determine whether the next store will be sold to a franchisee, or whether the chain will operate it themselves. Especially with more experience, a talented franchisor will be able to determine whether it is best to sell the establishment or operate it themselves. Franchisees do not own $100 \%$ of the restaurants in the sample, and because the franchisors are acting rationally, it must be profit maximizing to keep some restaurants owned by the franchisor. If the franchisor is good at determining which stores should be in which category, then there should be little difference. The fact that there is a positive and significant effect in full service shows that franchisees really do make a difference when management motivation can be a difference maker, such as when higher levels of training are possible.

This is an important contribution to the franchising literature. This is a much larger, and much more comprehensive study that has been done on franchising's outcomes. These results are confirmation that the agency theory is accurate in explaining the motivation behind franchising. By franchising the restaurant is able to ensure that the manager has an incentive to work hard. And because we find an effect in the subsector that has the most managerial impact, it is clear that a motivated franchisee can make a difference in the efficiency of the restaurant.

\section{Conclusion}

In this paper we present a two-stage DEA model on the efficiency differences between franchiseeowned and franchisor-owned restaurants in the full and limited service subsectors. We find that there 
is no noticeable franchisee-ownership effect in limited service. However, we find a strong positive, statistically significant franchisee-ownership effect for full service restaurants. This result is robust to various specification changes. Even after including different control variables, such as the number of units the owner owns, Census tract demographic information, and state fixed effects, we still find a positive and significant effect. This positive effect also holds steady when we switch from a multiple output to a single output specification of the DEA step. This is an exciting finding because it shows that franchisees can make a difference, which is an indication that the agency theory of franchising is correct. We explain the difference between the results for limited service and full service by the level of managerial control in the two subsectors. In the subsector where managers exert more control a larger effect is found. Again, this fits with the agency theory.

This paper makes an important contribution to the franchising literature. Since very little previous work has examined outcomes from the franchise decision, this paper fills that gap. While future work can expand on these results by including a panel dimension, the present results make significant inroads in investigating the results of the franchise decision. 


\section{References}

Achabal, Dale D, John M Heineke, and Shelby H McIntyre, "Issues and Perspectives on Retail Productivity," Journal of Retailing, October 1984, 60 (3), 1-23.

Affuso, Luisa, "An Empirical Study on Contractual Heterogeneity Within the Firm: The 'Vertical Integration-Franchise Contracts' Mix," Applied Economics, 2002, 34, 1-16.

Beheler, Roy, Seth W. Norton, and Kabir C. Sen, "A Comparison of Company Owned and Franchised Fast Food Outlet Performance: Insights from Health Inspection Scores," Strategy and Governance of Networks, 2008, pp. 113-125.

Bhattacharyya, Sugato and Francine Lafontaine, "Double-Sided Moral Hazard and the Nature of Share Contracts," The Rand Journal of Economics, January 1995, 26 (4), 761.

Botti, Laurent, Walter Briec, and Gérard Cliquet, "Plural Forms Versus Franchise and Company-Owned Systems: A DEA Approach of Hotel Chain Performance," Omega, June 2009, $37(3), 566-578$.

Brickley, James A, "Incentive Conflicts and Contractual Restraints: Evidence from Franchising," Journal of Law and Economics, October 1999, 42 (2), 745-774.

Census, "American Fact Finder," 2012.

Donthu, Naveen and Boonghee Yoo, "Retail ProductivityAssessment Using Data Envelopment Analysis," Journal of Retailing, 1998, 71 (1), 1-17.

Emerson, Robert, "Franchise Contract Clauses and the Franchisor's Duty of Care toward Its Franchisees," NCL Review, 1993, 72, 905.

Hwang, Shiuh-Nan and Te-Yi Chang, "Using Data Envelopment Analysis to Measure Hotel Managerial Efficiency Change in Taiwan," Tourism Management, August 2003, 24 (4), 357-369.

Joo, Seong-Jong, Philipp A Stoeberl, and Kristin Fitzer, "Measuring and benchmarking the performance of coffee stores for retail operations," Benchmarking: An International Journal, 2009, $16(6), 741-753$.

Keh, Hean Tat and Singfat Chu, "Retail Productivity and Scale Economies at the Firm Level: a DEA Approach," The International Journal of Management Science, April 2003, 31 (2), 75-82.

Lafontaine, Francine, "Agency Theory and Franchising: Some Empirical Results," The Rand Journal of Economics, July 1992, 23 (2), 1-21.

- and Kathryn Shaw, "Targeting Managerial Control: Evidence from Franchising," The Rand Journal of Economics, 2005, 36 (1), 131.

- and Roger Blair, The Economics of Franchising, Cambridge: Cambridge University Press, April 2005.

McDonald, John, "Using least squares and tobit in second stage DEA efficiency analyses," European Journal of Operational Research, 2009, 197 (2), 792 - 798.

Ménard, Calude, "The Economics of Hybrid Organizations," Journal of Institutional and Theoretical Economics, September 2004, 160 (3), 345-376.

Metters, Richard D, Frances X Frei, and Vincant A Vargas, "Measurement of Multiple Sites in Service Firms with Data Envelopment Analysis," Production and Operations Management, October 1999, $8(3), 1-18$.

Norton, Seth W, "Franchising, Labor Productivity, and the New Institutional Economics," Journal of Instiutional and Theoretical Economics, 1989, 145 (4), 578-596. 
Ray, Subhash, Data Envelopment Analysis: Theory and Techniques for Economics and Operations Research, Cambridge: Cambridge University Press, June 2004.

Reynolds, Dennis, "Productivity Analysis In the On-Site Food Service Segment," Cornell Hotel and Restaurant Administration Quarterly, June 1998, 39 (3), 22-32.

- and Gary M Thompson, "Multiunit Restaurant Productivity Assessment Using Three-Phase Data Envelopment Analysis," International Journal of Hospitality Management, March 2007, 26 (1), 20-32.

Rubin, Paul H, "The Theory of the Firm and the Structure of the Franchise Contract," Journal of Law and Economics, April 1978, 21 (1), 1-12.

Shelton, John P, "Allocative Efficiency vs. "X-Efficiency": Comment," The American Economic Review, 1967, 57 (5), 1252-1258.

Simar, Leopold and Paul Wilson, "Estimation and Inference in Two-Stage, Semi-Parametric Models of Production Processes," Journal of Econometrics, 2007, 136 (1).

Sveum, Matthew, "Management Differences and Productivity: A Simulated Investigation into Dummy Variables in Two-Stage Data Envelopment Analysis," University of Missouri Working Paper, 2016.

Zhang, Yun and Robert Bartles, "The Effect of Sample Size on the Mean Efficiency in DEA with an Application to Electricity Distribution in Australia, Sweden, and New Zealand," Journal of Productivity Analysis, 1998, pp. 187-204. 